Gulawentah: Jurnal Studi Sosial

ISSN 2528-6293 (Print); ISSN 2528-6871 (Online)

Vol. 6, No. 1, Juni 2021, Hal 17-30

Tersedia Online: http://e-journal.unipma.ac.id/index.php/gulawentah

\title{
Meneropong potensi kemunduran upaya kesetaraan gender dalam RUU Ketahanan Keluarga
}

\author{
Dwi Astuti \\ Prodi Sosiologi/Fakultas Ilmu Sosial dan Ilmu Politik, Universitas Widya Mataram, \\ Dalem Mangkubumen KT III/237 Yogyakarta, Indonesia \\ Email:*dwiastuti@gmail.com
}

Naskah diterima: 22/04/2021; Revisi: 03/05/2021; Disetujui: 21/05/2021

\begin{abstract}
Abstrak
Kesetaraan gender merupakan kondisi terjadinya keseimbangan dan keadilan antara laki-laki dan perempuan dalam banyak hal. Salah satunya adalah keadilan dan keseimbangan dalam memberikan kesempatan untuk berperan di ruang publik bagi laki-laki dan perempuan Pengesahan RUU Ketahanan Keluarga akan berpotensi memumculkan domestifikasi pada perempuan, yaitu pembatasan ruang gerak perempuan di ruang publik dan ketidakadilan pembagian ruang publik antara laki-laki dan perempuan. Penelitian ini menggunakan metode kajian pustaka dengan analisis menggunakan pendekatan Analisis Wacana Kritis. Analisis Wacana Kritis adalah metode kajian yang menganalisis teks dengan mangambil posisi berpihak dan mendemistifikasi bentuk-bentuk dominasi dengan melalui analisis kritis. Tujuan dari metode AWK adalah untuk membongkar bentuk-bentuk dominasi dan diskriminasi yang biasanya atas dasar gender, etnis, kelas, agama atau bahasa. Dalam penelitian ini ditemukan bahwa pendefinisian peran perempuan dalam RUU Ketahanan Keluarga didasarkan kepada konstruksi pemikiarn yang bias gender, sehingga menimbulkan proses domestifikasi terhadap peran perempuan. Domestifikasi peran perempaun selanjutnya akan berdampak kepada diskriminasi kepada perempuan dan lebih jauh akan menghambat upaya kesetaraan gender di Indonesia.
\end{abstract}

Kata kunci: RUU Ketahahan Keluarga; Domestifikasi Perempuan; Kesetaraaan Gender

\section{Looking at the potential seatback for gender equality in the Omnibus Bill on Family Resilience}

\begin{abstract}
Talking about domestic and public sphere, gender equality is a condition that is a balance and fairness of the devision of domestic sphere and public sphere between men and woman. The plan to ratify the Omnibus Bill on Family Resilience potentially create domestification for women. The process that was limiting the opportunity for women to move in public sphere. Or in another words is a condition where there is an inbalance of the devision of domestic and public roles between men dan women. This study used a literature review method and has been alalyzed with Critical Discourse Analisys approach. Critical Discourse Analysis is a method that analyze text by taking sides and demystifying forms of domination through critical analysis. The purpose of the Critical Discourse Analysis is to dismantle forms of domination and discrimination which are usually based on gender, ethnicity, class, religion or language. In this study it was found that defining the role of woman in the Omnibus Bill on Familiy Resilience was based on gender bias. Gender bias as a social construction has the potential to reproduce and reinforce. This domestification process can create gender inequality and more than that will create discrimination.
\end{abstract}

DOI: 10.25273/gulawentah.v6i1.9076

Some rights reserved. 
Keywords: Omnibus Bill on Family Resseilince; Women Domestification; Gender Quality

\section{Pendahuluan}

Kiprah perempuan di ranah publik bukan merupakan hal baru di masyarakat, namun persoalan ini selalu menarik untuk diperdebatkan. Peran publik merupakan peran yang terkait dengan persoalan-persoalan di luar rumah tangga, seperti mencari nafkah atau beraktifitas sosial di tengah-tengah masyarakat. Peran domestika banyak terkait dengan peran di dalam rumah tangga, seperti melayani anggota keluarga, mengasuh anak, merawat anggota keluarga yang sakit, memasak, mencuci dan lain sebagainya. Sampai sekarang masyarakat masih sering memperdebatkan tentang kepantasan atau kelayakan peran yang dilakukan laki-laki maupun perempuan di ranah domestik maupun publik. Perdebatan ini tidak lain didasari oleh konstruksi berpikir masyarakat tentang kepantasan peran yang dilekatkan pada laki-laki dan perempuan. Konstruksi berpikir ini pun bisa berbeda antara satu budaya dengan budaya lainnya, dan bisa berbeda antara satu masa dengan masa lainnya. Fenomena perempuan yang bersekolah tinggi, bekerja di luar rumah, menjadi pimpinan politik, mungkin belum banyak terjadi di masa lalu, namun di jaman sekarang sudah merupakan hal yang lumrah. Perempuan bekerja di ranah publik mungkin merupakan hal yang biasa di negara asing, atau di kota-kota besar di Indonesia seperti Jakarta, namun masih merupakan hal tidak lumrah di masyarakat pedesaan. Sebaliknya peran laki-laki dalam ruang domestik seperti mengerjakan pekerjaan rumah atau pekerjaan perawatana anak, dipandang pantas oleh masyarakat tertentu, namun tidak pantas oleh masyarakat lian, di tempat dan jaman yang berbeda.

Anggapan tentang kalayakan pembagian peran publik dan peran domestik ini sangat terkait erat dengan konstruksi gender. Dalam perspektif gender ada dua pemahaman yang mempengaruhi pembagian peran ini, yaitu pemahaman tentang jenis kelamin (sex) dan pemahaman tentang gender. Pembagian dua jenis kelamin laki-laki dan perempuan secara biologis, tidak begitu menimbulkan perdebatan karena perbedaan secara biologis tersebut merupakan bawaan atau pemberian dari Tuhan. Yang menarik adalah pembedaan laki-laki dan perempuan berdasarkan peran-peran yang dilekatkan oleh masyarakat, yang dikenal dengan peran gender. Peran gender terus mengalami perdebatan di masyarakat dan terus mengalami perubahan. Mengacu kepada makna dari gender, maka peran gender yang melekat pada laki-laki dan perempuan bisa mengalami pergeseran sesuai dengan pergeseran konstruksi pemikiran masyarakat dimana peran itu ada. Peran sosial gender sangat tergantung dari konstruksi masyarakat dan konteks masyarakatnya, sehingga ketika masyarakat berubah, maka peran gender yang ditetapkan dalam masyarakat tersebut juga berubah (Astuti, 2020).

Begitu juga dengan pergeseran peran gender di Indonesia. Di Indonesia, perubahan konstruksi peran laki-laki dan peran perempuan secara sosial, selain dipengaruhi oleh proses perubahan sosial di masyarakat, juga dipengaruhi kebijakan pemerintah. Berbagai kebijakan dibuat pemerintah untuk meningkatkan keterlibatan perempuan dalam ruang publik. Beberapa alasan pentingnya pelibatan perempuan dalam ruang publik antara lain: Pertama, terkait dengan partisipasi seluruh masyarakat dalam proses pembangunan. Di dalam GBHN disebutkan bahwa pembangunan bukan hanya menjadi tanggung jawab pemerintah tetapi juga harus melibatkan partisipasi masyarakat secara luas dan merata. Partisipasi disini dimaknai sebagai bersama-sama memikul beban tanggung jawab dalam pelaksanaan maupun menerima hasil-hasil pembangunan (Hasanah \& Musyafak, 2017). Partisipasi dalam pembangunan 
merupakan peran seseorang atau sekelompok orang (masyarakat) yang terlibat secara aktif dan sadar untuk berkontribusi dalam pembangunan secara sukarela mulai dari proses perencanaan, pelaksanaan, monitoring sampai tahap evaluasi (Monica \& Fauziah, 2019).

Kedua, semakin pentingnya peran ekonomi perempuan untuk mewujudkan kesejahteraan keluarga. Secara nasional keterlibatan perempuan sebagai pencari nafkah dalam keluarganya dapat dilihat dari Tingkat Partisipasi Angkatan Kerja (TPAK). Berdasarkan data yang diterbitkan Badan Pusat Statistik tahun 2011, TPAK berdasarkan jenis kelamin adalah $80,91 \%$ untuk laki-laki dan $49,75 \%$ untuk perempuan. Selanjutnya pada tahun 2012 TPAK laki-laki sebesar $84,21 \%$ dan untuk perempuan sebesar 51,39, di tahun 2013 TPAK laki-laki sebesar 83,37 dan perempuan sebesar 52,26. Sementara tahun 2014 TPAK untuk laki-laki sebesar 83,05 dan untuk perempuan sebesar 50,22 (Mayanti \& Bachtiar, 2018). Dari data tersebut dapat dilihat bahwa meskipun angka partisipasi perempuan bekerja selalu lebih rendah dari laki-laki, namun ada kecenderungan partisipasi perempuan bekerja semakin tinggi dari tahun ke tahun. Faktor yang mempengaruhi fenomena ini adalah perluasan kesempatan kerja yaitu sektor informal. Lapangan kerja di sektor formal tidak selalu bisa menyerap seluruh tenaga kerja yang tersedia, sehingga memunculkan sektor informal yang mana sektor informal ini merupakan sektor yang banyak dimasukki oleh perempuan (Fitlayeni, 2009). Pada umumya perempuan bekerja bukan untuk memikirkan karir, tetapi untuk memenuhi nafkah keluarganya, memenuhi kebutuhan hidup keluarganya, serta membantu dan menunjang perekonomian keluarganya ketika pendapatan suami tidak mencukupi (Aswiyati, 2016).

Ketiga, terjadinya proses modernisasi. Modernisasi adalah proses yang membawa dan menawarkan nilai-nilai baru di masyarakat yang bisa berpengaruh merubah anggapan masyarakat tentang peran perempuan. Nilai-nilai rasionalitas yang dibawa oleh proses modernisasi, berpengaruh kepada cara masyarakat dalam memaknai dan membagi peran antara laki-laki dan perempuan (Astuti, 2020). Modernisasi telah berdampak kepada konstruksi berpikir masyarakat dalam memberikan peran kepada laki-laki dan perempuan, khususnya dalam beberapa bidang yaitu pendidikan, ekonomi dan politik. Jika dahulu kesempatan pendidikan khususnya pendidikan tinggi hanya diberikan kepada laki-laki, maka saat ini kesempatan pendidikan, baik pendidikan dasar maupun pendidikan tinggi antara laki-laki dan perempuan sudah sama. Begitu juga dengan kesempatan ekonomi, jika dahulu masyarakat memberikan peran mencari nafkah hanya kepada laki-laki dan perempuan hanya sebagai ibu rumah tangga, maka dalam masyarakat modern perempuan dan laki-laki memiliki akses yang sama dalam peran ekonomi. Pergeseran peran ini juga terjadi pada aspek politik. Dunia politik dahulu merupakan dunia milik laki-laki, masyarakat menganggap tidak pantas ketika perempuan tampil sebagai pemimpin. Namun samakin modern, kesempatan untuk tampil dalam panggung politik sama antara laki-laki dan perempuan (Astuti, 2020).

Dengan tiga fakta diatas, menjadi keharusan bagi pemerintah Indonesia untuk mengupayakan keterlibatan perempuan dalam proses pembangunan secara makro dan melibatkan perempuan dalam ranah publik secara mikro. Indonesia mencatat beberapa program pemberdayaan perempuan sebagai upaya pelibatan perempuan di ruang publik. Secara garis besar ada tiga pendekatan yang dipakai oleh beberapa negara dalam melakukan proses pemberdayaan perempuan dan diakomodasi oleh Indonesia. Ketiga pendekatan itu adalah Women in Development (WID), Woman and Development 
(WAD) dan Gender and Development. Pendekatan Woman in Development adalan pemberdayaan perempuan yang menitikberatkan kepada bagaimana mengupayakan efisiensi pekerjaan perempuan sehingga mereka bisa lebih berperan dalam sektor publik. Pendekatan ini dianggap kurang mampu memberikan hasil terhadap upaya pemberdayaan perempuan karena sebenarnya yang menjadi masalah utama adalah kemampuan perempuan untuk terlibat di ruang publik. Dengan kelemahan pendekatan WID kemudian ditetapkan pendekatan baru yaitu WAD, pendekatan yang lebih menekankan kepada upaya untuk meningkatkan pengetahuan dan ketrampilan perempuan dan berbagai bantuan material kepada perempuan, supaya dengan pengetahuan dan ketrampilan yang dimiliki bisa lebih berperan dalam pembangunan. Pendekatan ini pun dianggap memiliki kelemahan karena masih menyisakan persoalan yaitu, disadari bahwa rendahnya peran perempuan dalam pembangunan sesungguhnya terkait erat dengan masalah strukur dan sistem yang patriarki. Dengan kesadaran ini muncul pedekatan baru yang dikenal dengan Gender and Development (GAD), dimana pendekatan ini berfokus pada upaya menyelesaikan persoalan peran perempuan dalam pembangunan dengan merubah struktur dan sistem yang masih patriarki agar lebih setara.

Indonesia juga mengupayakan pemberdayaan perempuan dengan agenda gendernya yang dikenal dengan pengarusutamaan gender. Keseriusan pemerintah terhadap persoalan perempuan di Indonesia juga dibuktikan tahun 1978 ketika pemerintah menunjuk jabatan Menteri Muda Urusan Peranan Wanita. Bahkan tuntutan peran wanita untuk terlibat dalam pembangunan ditegaskan juga dalam GBHN yang ditetapkan tahun 1978, yaitu wanita memiliki hak, kewajiban dan kesempatan yang sama dengan pria untuk ikut sepenuhnya dalam semua proses pembangunan (Nugroho, 2008). Selain megadopsi konsep WID dan GAD, Indonesia juga menetapkan konsep Gender Mainstreaming (GM) atau Pengarusutamaan Gender. Jika diperhatikan operasionalisasi dari konsep Gender Mainstreaming ini memang lebih menyeluruh dan lebih strategis. Konsep ini dibuat untuk mendukung keterlibatan perempuan dalam pembangunan. Mengadopsi konsep Gender Mainstreaming yang ditetapkan di Beijing tahun 1995, konsep ini menetapkan bahwa pemerintah dan para pengambil keputusan harus terlebih dahulu aktif mempromosikan rencana, program dan kebijakan berperspektif gender. Konsep ini mengorganisir proses kebijakan, pelakasanaan dan evaluasinya supaya semua memiliki perspektif gender. Jadi harus dipastikan siapa yang terlibat, langkah apa yang ditempuh dan siapa yang bertanggungjawab, harus memahami perspektif gender (Nugroho, 2008). Kebijakan tentang Gender Mainstreaming atau Pengarusutamaan Gender di Indonesia ini ditetapkan dalam Instruksi Presiden (Inpres) nomor 9 Tahun 2000 tentang PUG dalam pembangunan nasional dan Permendagri Nomor 15 Tahun 2008 tentang pelaksanaan pengarusutamaan gender. Dengan kedua kebijakan ini diharapkan kebijakan, program dan kegiatan pembangunan baik di tingkat nasional maupun daerah bisa berperspektif gender (Hasan \& Matoka, 2016).

Dalam beberapa dasawarsa ini Indonesia telah menerbitkan dan mengeluarkan keputusan untuk meratifikasi berbagai paraturan perundang-undangan, dimana semuanya memiliki tujuan untuk melibatkan perempuan dalam proses pembangunan, meningkatkan partisipasi perempuan dalam pembangunan dan menurunkan tindakan ketidakadilan gender. Seperti diterbitkanyya UNdang-Undang Nomor 16 tahun 2019 sebagai perubahan terhadap Undang-Undang Nomor 1 tahun 1974, ratifikasi Convention on the Ellimination of all Forms of Discrimination Againts Women 
(CEDAW), UU Nomor 7 tahun 1984 tentang penghapusan segala bentuk diskriminasi terhadap perempuan, UU Penghapusan Kekerasan dalam Rumah Tangga, UU Perlindungan Saksi korban terkait kekerasan kepada perempuan, dan masih banyak lagi Namun demikian komitmen pemerintah untuk melibatkan perempuan dalam ruang publik dirasa belum maksimal, karena seringnya muncul ketidakselarasan antara satu kebijakan dangan kebijakan yang lain.

Di tengah-tengah berbagai upaya pemberdayaan terhadap perempuan atau upaya kesetaraan gender, dibuatlah RUU Ketahanan Keluarga yang ditengarai memunculkan potensi domestifikasi peran perempuan (Kurniasari, 2021). Potensi ini muncul karena di dalam RUU Ketahanan Keluarga diatur tentang tugas dan tanggung jawab suami dan istri, yaitu pasal 25 ayat (2) dimana disebutkan ada empat kewajiban suami, yaitu: 1) Sebagai kepala keluarga yang bertanggung jawab untuk menjaga keutuhan dan kesejahteraan keluarga, memberikan keperluan hidup berumah tangga sesuai dengan kemampuannya, dan bertanggung jawab atas legalitas kependudukan keluarga; 2) Melindungi keluarga dari diskriminasi, kekejaman, kejahatan, penganiayaan, eksploitasi, penyimpangan seksual, dan penelantaran; 3) Melindungi diri dan keluarga dari perjudian, pornografi, pergaulan dan seks bebas, serta penyalahgunaan narkotika, alkohol, psikotropika, dan zat adiktif lainnya; serta 4) melakukan musyawarah dengan seluruh anggota keluarga dalam menangani permasalahan keluarga. Sementara itu, kewajiban istri diatur di dalam Ayat (3) yaitu: 1) wajib mengatur urusan rumah tangga sebaik-baiknya; 2) menjaga keutuhan keluarga; serta 3) memperlakukan suami dan anak secara baik, serta memenuhi hak-hak suami dan anak sesuai norma agama, etika sosial, dan ketentuan peraturan perundang-undangan

Pengaturan ini menimbulkan pertanyaan terkait persoalan gender, apakah RUU Ketahanan Keluarga ini nantinya justru tidak akan kontradiktif dengan upaya kesetaraan gender dan peningkatan peran perempuan dalam pembangunan? Tulisan ini menjelaskan adanya potensi kemunduran kesetaraan gender di Indonesia dengan adanya RUU Ketahanan Keluarga.

\section{Metode Penelitian}

Penelitian ini menggunakan metode kajian pustaka dengan pendekatan Analisis Wacana Kritis (AWK), dimana metode ini merupakan metode pemahaman teks dan konteks dipahami sebagai praksis sosial. Teks dalam penelitian ini berupa produk hukum yaitu bagian pasal dari RUU Ketahanan Keluarga. Berbeda dengan analisis wacana obyektif yang menganalisis masalah dengan mengambil jarak, hubungan peneliti dengan teks bersifat obyektif dan tidak mengambil posisi tertentu, maka Analisis Wacana Kritis adalah metode kajian yang menganalisis teks dengan mangambil posisi berpihak dan mendemistifikasi bentuk-bentuk dominasi dengan melalui analisis kritis. Metode analisis AWK ini memang ada keberpihakan akan tanggung jawab moral dan politik. Tujuan dari metode AWK adalah untuk membongkar bentuk-bentuk dominasi dan diskriminasi yang biasanya atas dasar gender, etnis, kelas, agama atau bahasa (Haryatmoko, 2016).

Langkah-langkah dari metode AWK ini adalah pertama, menemukan ketidakberesan sosial dalam aspek semiotik, kedua mengidentifikasi hambatanhambatan untuk mengatasi ketidakberesan sosial itu, ketiga, mengidentifikasi apakah tatanan masyarakat memang membutuhkan ketidakberasan dalam teks tersebu, keempat, mengidentifikasi langkah-langkah yang mungkin untuk mengatasi 
ketidakberesan (Haryatmoko, 2016). Dengan metode ini, maka penelitian ini akan mampu untuk menandai atau mengidentifikasi teks yang bermasalah dalam RUU Ketahanan Keluarga, mengidentifikasi hambatan-hambatan dalam menyelesaikan masalah tersebut dalam teks, mendiskripsikan bagaimana teks tersbut sebenarnya sangat tidak diperlukan dalam praksis dan tatanan sosial dan mengusulkan solusi untuk mengatasi masalah ketidakberesan tersebut.

\section{Hasil dan Pembahasan}

Tulisan ini secara khusus akan menyoroti dan mengkritisi bagian didalam RUU Ketahanan Keluarga yang bisa berpotensi menimbulkan proses domestifikasi terhadap peran perempuan dan berpotensi menimbulkan ketidaksetaraan gender (Nofianti, 2016). Rancangan Undang-Undangs Ketahanan Keluarga adalah rancangan undang-undang yang dilatar belakangi oleh pemikiran bahwa keluarga merupakan unit paling kecil yang sangat berpengaruh terhadap sistem sosial masyarakat dan selanjutnya akan mempengaruhi kehidupan bernegara atau stabilitas kehidupan bernegara. Ketika keluarga memiliki ketahanan dan stabilitas yang bagus dalam menghadapi berbagai perubahan baik perubahan sosial, perubahan budaya maupun perubahan ekonomi maka hal itu akan berdampak kepada terwujudnya ketahanan bangsa (Naskah Akademik Rancangan Undang-Undang Tentang Ketahanan Keluarga, 2009).

Rancangan Undang-Undang Ketahanan Keluarga sarat akan beberapa masalah yang menuai kritik dari banyak pihak. Beberapa kritik yang disampaikan antara lain adalah karena RUU ini dianggap terlalu mencampuri ruang privat, ada juga beberapa pendapat yang mengatakan bahwa RUU ini tumpang tindih dengan berbagai aturan yang ada seperti aturan agama serta dianggap sarat dengan diskriminasi gender terkait pembagian kewajiban suami dan istri (RUU Ketahanan Keluarga). Persoalan tentang pembagian kewajiban antara suami dan istri ini, bahkan disebutkan dalam banyak pemberitaan sebagai pasal yang kontroversial dan perlu dikritisi. Beberapa persoalan yang dijadikan sebagai alasan perlunya RUU Ketahanan Keluarga antara lain: tigginya angka kematian ibu, tingginya angka kematian bayi, kesehatan keluarga yang belum sepenuhnya terpenuhi, rumah tidak layak, tingginya angka perceraian, tingginya perilaku merokok anak, tingginya kekerasan seksual, dan terakhir adalah masih minimnya kebijakan atau program pembangunan yang terkait dengan ketahanan keluarga (Naskah Akademik Rancangan Undang-Undang Tentang Ketahanan Keluarga, 2009).

Memperhatikan kondisi keluarga Indonesia yang dijadikan indikator lahirnya RUU Ketahaan Keluarga diatas, ada banyak sekali celah yang perlu dikritisi. Pemaparan persoalan-persoalan diatas tidak didukung oleh analisis yang memadai, apakah kondisi-kondisi itu memang disebabkan oleh pembagian peran antara suami dan istri, atau ada sebab yang lain. Pemaparan kondisi-kondisi keluarga Indonesia diatas tidak secara langsung menunjukkan adanya kebutuhan terhadap UU baru yang mengatur tentang keluarga, apalagi jika Undang-Undang baru tersebut justru berpotensi menimbulkan diskriminasi terhadap relasi gender dalam masyarakat. Pengaturan yang mengatasnamakan perlindungan keluarga namun tidak didasarakan kepada pemahaman yang utuh dan jelas tentang kekerasan dan diksriminasi justru akan menghalangi terwujudnya keadilan dan menghalangi terwujudnya tujuan nasional (Komnas Perempuan, 2020)

Kasus lain yang dipaparkan yang menjadi alasan pentingnya RUU Katahanan Keluarga adalah adanya dampak yang dialami keluarga yang ditinggalkan oleh 
perempuan yang bekerja dalam waktu yang cukup lama, yaitu keluarga yang istri atau ibunya bekerja sebagai TKI. Disebutkan dampak dari keluarga yang istri atau ibunya bekerja sebagai TKI adalah : 1) disharmonisasi keluarga, 2) pengasuhan anak tidak memadai, 3) pemanfaatan uang kiriman kurang maksimal. Sama dengan kritikan yang muncul atas indikator-indikator kondisi keluarga yang mendasari pentingya RUU Ketahanan Keluarga seperti yang dipaparkan pada pembahasan sebelumnya, alasan ini juga penuh dengan celah atau ketidak lengkapan dan ketidak jelasan analisis terhadap fakta. Terkait dengan disharmonisasi, tidak dilihat dengan lebih jelas kemungkinan disharmoni juga terjadi pada keluarga yang ditinggalkan bekerja oleh laki-laki. Disana juga tidak dijelaskan dengan lengkap apa sebab timbulnya disharmonisasi, apakah ibu atau istri yang bekerja sebagai sebab tunggal atau ada sebab yang lainnya. Disharmonisasi bisa saja terjadi karena ketidakcapakan laki-laki dalam mengelola rumah tangga yang ditinggalkan istri/ibu. Terkait dengan pengsuhan anak, juga tidak dijelaskan dengan lengkap sebab-sebab mengapa pengasuhan dianggap tidak memadai. Kepergian seorang ibu untuk bekerja tidak secara langsung berdampak kepada pengasuhan anak, karena sebenarnya ada keluarga lain yang mengasuh ketika ibu bekerja. Melihat kondisi ini sebenarnya bisa juga kita pahami bahwa persoalan disharmonisasi keluarga dan tidak memadainya pengasuhan anak pada keluarga TKI justru terjadi karena laki-laki tidak mampu bertukar peran ketika perempuan harus mencari nafkah. Kembali menempatkan perempuan pada ruang domestik bukan merupakan solusi, apalagi jika fakta menunjukkan dimana di dalam suatu keluarga justru perempuan yang lebih memiliki kemampuan untuk mencai nafkah. Yang harus dilakukan adalah menghilangkan bias pembagian peran pada laki-laki dan perempuan sehingga keduanya memiliki kemampuan yang sama dalam menangani persoalan domestik maupun publik dan bisa bertukar peran.

\section{Mengupas RUU Ketahanan Keluarga Sebagai Proses Domestifikasi Peran Perempuan.}

Pasal ini sangat menarik untuk dikritisi dari persepektif gender, yaitu penempatan kerja produktif pada laki-laki (suami) dan kerja reproduktif pada perempuan (istri). Pekerjaan produktif adalah pekerjaan yang berkaitan dengan upaya pemenuhan kebutuhan secara ekonomi, sementara pekerjaan reproduktif adalah pekerjaan yang terkait dengan peran memelihara dan merawat seluruh anggota keluarga dan tidak menimbulkan dampak ekonomi.

Masyarakat menempatkan perempuan dan laki-laki dalam ruang peran yang berbeda, yaitu peran domestik dan peran publik. Konstruksi peran gender mendikotomikan laki-laki dan perempuan dalam runag-ruang aktivitas yang berbeda, yaitu ruang domestik dan ruang publik. Ruang domestik adalah ruang yang berada di bawah kekuasaan ayah (pater familias) (Gelgel, 2016). Ruang privat atau ruang domestik adalah segala bentuk perbuatan dan nilai yang berada di sekitar rumah tangga, yang masuk di dalamnya adalah kebutuhan rumah tangga, urusan keluarga dan masalah keagamaan (Gelgel, 2016). Sementara ruang yang satunya lagi adalah ruang publik. Makna kata publik adalah sebagai "ruang" yaitu ruang yang menjadi milik umum dan "subyek" yang maknanya rakyat atau negara. Jika diartikan ruang ini sebagai ruang sosial maka maknanya menjadi ruang yang bisa dilibati banyak orang (Gelgel, 2016). Beberapa arti dari ruang publik adalah, pertama, mengacu pada ruang yang bisa diakses semua orang, kedua, ruang yang bebeda dari ruang privat yang merupakan wilayah intimitas. 
Menurut Gelgel (2016) Ruang publik sering juga diterjemahkan sebagai ruang diantara negara dan ruang privat. Beberapa ahli menyebut peran domestik perempuan dengan sebutan jenis pekerajaan reproduktif. Pekerjaan yang dilakukan adalah pekerjaan perawatan dan pelayanan yang dilaksanakan dalam ruang domestik atau rumah tangga. Beberapa jenis pekerjaan yang masuk dalam kategori domestik atau reproduktif ini adalah memasak, mengsuh anak, menjaga lansia, membersihkan rumah, mencuci dan seterika (Sukesi, 2009). Sampai saat ini masyarakat masih sering bias dalam memahami dan menempatkan posisi kerja produktif dan kerja reproduktif.

Munculnya dikotomi pekerjaan rumahtangga dan pekerjaan publik ini, terkait erat dengan proses perubahan sosial dalam masyarakat. Pergeseran peran gender terkait dengan terjadinya transformasi sistem ekonomi yang ada yaitu pergeseran dari 1) the family base-economi, rumah tangga menjadi basis kegiatan ekonomi. Kegiatan produksi banyak dilakukan di dalam rumah. Kerja dikonsepsikan sebagai aktivitas produktif bagi pemenuhan kebutuhan rumah tangga. Semua anggota keluarga (termasuk anak-anak) memiliki kontribusi yang berarti terhadap proses produksi. Perempuan atau istri bahkan memiliki posisi sentral dalam keluarga karena bertanggung jawab terhadap sebagian terbesar pekerjaan rumah. Sehingga perempuan memiliki peran penting dalam keluarga, perempuan tidak hanya bekerja di dalam rumah namun juga terlibat dalam kegiatan luar rumah misalnya pertanian, perdagangan atau kerajinan. Kegiatan perempuan dan pria memang berbeda namun memiki hubungan ketergantungan satu sama lain. 2) The family-wage economy, sejajar dengan kapitalisme, kegiatan bertransformasi dari pertanian ke perdagangan. Konsentrasi kegiatan tidak lagi dalam rumah tangga tetapi di luar rumah sebagai pekerja dari proses industrialisasi. Misalnya bekerja di pabrik-pabrik, berdagang dan sebagainya. Dan kebutuhan rumah tangga dipenuhi dari upah ketika bekerja di luar rumah. Pergeseran ini membawa perempuan pada peran ganda, di satu pihak sebagai ibu rumah tangga (alami) di lain pihak juga sebagai tenaga kerja. Pekerjaan perempuan di rumah tetap diperlukan, tetapi nilai kerja seseorang lebih diukur dari upah yang diperolehnya. Fokus pada penghasilan ini membuat pekerjaan di luar rumah lebih dihargai dan pekerjaan rumah kurang dihargai. Status dan peran perempuan menjadi kurang sejajar dengan laki-laki. 3) The familyconsumer economy, terjadi perubahan teknologi yang cukup pesat dan peningkatan produktivitas, dalam perkembangannya membuat anggota rumah tangga hanya melakukan kegiatan konsumsi dan reproduksi saja. Tenaga kerja yang merupakan anggota keluarga memberikan kontribusi berarti dalam ekonomi tumah tangga. Karena beban peran ganda, produktivitas perempuan bahkan lebih tinggi dari laki-laki dan dari periode sebelumnya. Sayangnya sebagian besar curahan keringat perempuan tidak mendatangkan uang tunai sehingga perannya tidak begitu diperhitungkan. Terlebih lagi ketika pekerjaan perempuan digantikan oleh berbagai institusi publik, seperti sekolah, industri makanan, loundry dan sebagainya, semakin menempatkan perempuan yang tidak menghasilkan uang sebagai penerima (consumer) saja (Usman, 1998).

Dalam masyarakat subsisten, dimana keluarga merupakan unit yang mencukupi segala kebutuhannya sendiri, peran perempuan dengan laki-laki sangat seimbang. Misalnya dalam masyarakat agraris, dimana laki-laki dan perempuan memiliki peran yang hampir sama dalam memenuhi kebutuhan hidup keluarganya, maka posisi kerja antara perempuan dan laki-laki sangatlah seimbang, dan mendapatkan penghargaan yang sama. Setiap pekerjaan baik yang dilakukan oleh laki-laki maupun oleh perempuan memiliki nilai yang sama dalam masyarakat. 
Perubahan stuktur masyarakat dan struktur keluarga dari masyarakat subsisten menjadi masyarakat industri menimbulkan perubahan atas pemberian makna dan penghargaan kepada peran-peran pekerjaan perempuan. Dari proses perubahan ini telah berdampak kepada relasi gender sebagai berikut : 1) Perubahan pemberian makna dan penghargaan terhadap pekerjaan perempuan telah menimbulkan terjadinya bias gender, kondisi ketika peran publik dan peran domestik dianggap senagai kodrat, padahal peran tersebut dibentuk, diciptakan dan disetujui masyarakat, 2) Masyarakat industri yang memberikan makna dan penghargaan yang rendah terhadap peran pekerjaan domestik yang dilakukan perempuan menjadi sumber sikap diskriminasi terhadap perempuan, 3) karena konstruksi masyarakat bahwa peran domestik adalah peran kodrati perempuan, sehingga perempuan yang sudah bekerja pun dihargai lebih rendah daripada laki-laki karena dianggap bukan pencari nafkah utama.

Sepanjang perjalanan bangsa Indonesia, beberapa kali pemerintah mengeluarkan kebijakan yang kontradiktif dengan penghargaan peran perempuan tersebut. Yang paling banyak dicatat adalah selama masa Orde Baru. Orde baru telah memberikan pemahaman gender yang berbeda. Pemerintah Orde Baru mempromosikan pemahaman dan sosok gender bagi perempuan Indonesia melalui berbagai sektor, seperti pendidikan sekolah, program kesehatan masyarakat, edukasi masa, dan berbagai program pembangunan lainnya (Davies, 2018). Juga dalam kebijakan-kebijakan tentang kebangsaan dan proses modernisasi bangsa Indonesia gender diproduksi sebagai alat untuk bangsa Indonesia.

Pada masa itu pemerintah Indonesia secara aktif mencari cara untuk mendefinisikan arti perempuan dalam masyarakat. Ketika itu pemerintah mendefinisikan bahwa perempuan dianggap memiliki peran yang hebat dan natural adalah dengan menjadi ibu bagi anak-anaknya dan menjaga kestabilan keluarganya, dan kestabilan keluarga memberikan konstribusi kepada kestabilan bangsa. Jadi peran perempuan ditempatkan dalam wacana perannya dalam keluarga sebagai cara berkontribusi pada bangsa lewat keluarga (Davies, 2018). Dalam kongres perempuan pertama tahun 1928 disebutkan bahwa "tanggung jawab seorang perempuan adalah menjadi istri yang setia kepada suami, bagi bangsa, bagi ibu pertiwi dan mencintai anak-anaknya. Dikenal dengan era "Ibuisme", pemerintah masa Orde Baru gencar mempromosikan tentang stabilitas keluarga batih dan menjadi ibu (motherhood). Dalam masa tersebut juga dikenal dengan Panca Dharma Wanita yaitu lima tanggung jawab sebagai perempuan, yaitu sebagai istri, ibu, prokreator, pengurus keuangan rumah tangga dan akhirnya anggota masyarakat (Davies, 2018).

Demikian juga dalam RUU Ketahan Keluarga, pembagian tugas seperti yang ditetapkan dalam RUU Ketahanan Keluarga bisa dimaknai sebagai proses domestifikasi. Yaitu suatu tatanan atau aturan yang secara tidak disadari di dalamnya memumculkan proses pembatasan perempuan untuk berperan di ruang publik. Bahkan kalau pun diberikan kesempatan tampil di ruang publik, namun dengan ketentuanketentuan yang sangat ketat (Fathoni, 2020). Domestifikasi juga bisa dimaknai sebagai budaya atau konstruksi yang memberikan porsi yang tidak seimbang dalam pengaturan peran domestik dan peran publik antara laki-laki dan perempuan, dan memicu rendahnya peran publik perempuan (Mukodi \& Burhanuddin, 2015). Penetapan istri dalam peran utama menjalankan rumah tangga dalam RUU Ketahanan Keluarga, adalah proses domestifikasi yang justru kembali menyebabkan posisi ketidaksetaraan gender dalam masyarakat. RUU Ketahanan Keluarga memiliki bagian yang berpotensi 
menimbulkan proses domestifikasi peran perempuan. Yang selanjutnya akan berdampak pada ketidaksetaraan posisi laki-laki dan perempuan dan menjadi penyebab munculnya tindakaan kekerasan.

\section{Potensi Kemunduran Kesetaraan Gender Dengan Pemberlakuan RUU Ketahanan Keluarga.}

Partisipasi perempuan dalam ranah publik, bisa dilihat dari angka pertisipasi kerja perempuan. Dari sudut pandang angka pertisipasi kerja perempuan, sampai saat ini memang perempuan cenderung dikategorikan sebagai bukan angkatan kerja, karena lebih cenderung menghasilkan produk yang dikonsumsi untuk rumah tangga mereka sendiri seperti menyiapkan dan menyajikan makanan untuk keluarga, merawat dan mengawasi anak, merawat orang sakit atau orang tua yang ada dalam rumah tangga. Konstruksi masyarakat yang beranggapan bahwa pekerjaan rumah tangga adalah pekerjaan perempuan seringkali mempengaruhi kebersediaan dan kesempatan perempuan untuk bekerja di ruang public (Perempuan, 2018). Sejauh ini peran publik perempuan bisa merupakan peran produktif yang menghasilkan pendapatan ataupun peran di masyarakat yang tidak menghasilkan keuntungan ekonomi.

Konstruksi peran domestik dan peran publik tidak lepas dari konstruksi gender di masyarakat. Masyarakat sampai saat ini masih sering mengalami bias dalam memahami pembagian peran ini, terkait dengan pemahaman masyarakat tentang gender. Pengertian jenis kelamin (sex) dan pengertian gender sangat berbeda. Jenis kelamin (sex) adalah pembagian dua kelompok manusia yang ditentukan secara biologis. Misalnya laki-laki memiliki penis, memiliki jakala, memproduksi sperma. Sedangkan perempuan memproduksi sel telur, memiliki alat reproduksi rahim, memiliki vagina, dan mempunyai alat menyusui. Alat-alat biologis tersebut tidak dapat dipertukarkan, tidak berubah dan merupakan kodrat (ketentuan Tuhan). Sedangkan konsep gender yaitu sifat yang melekat pada manuisa, laki-laki dan perempuan yang dikonstruksi secara sosial maupun kultural. Misalnya, laki-laki itu kuat, rasional, jantan, perkasa dll. Sementara perempuan lembut, cantik, emosional, keibuan. Ciri dari sifat laki-laki dan perempuan itu sendiri bisa dipertukarkan, bisa diubah maupun berubah dari waktu ke waktu, dan bisa berbeda dari satu budaya dengan budaya lain serta berbeda dari satu tempat dengan tempat lain (Fakih, 1996).

Sex is deemed category of analysis wich relates to the identification of an individual by biological endowments and functions. Sex invoked an analysis of men and woman based upon an a priori set of assumtions about how each sex behave". Dan "gender is use to classify humans and to explain their behaviour in predominantly social rather than biological form. Gender concern with the ascription of social characteristics such as womanly, manly, feminine and maskulin all of wich can be seen as culturall variable and not necessarelly associated with the sex of individua" (Browne, 2007).

Peran sosial berbasis gender sangat didasarkan pada konstruksi masyarakatnya, merupakan hasil kesepakatan dalam masyarakat dan bukan persoalan kodrat. Sehingga peran sosial yang ditetapkan ini pun juga bisa mengalami perubahan atau pergeseran sesuai dengan perubahan sosial yang ada di masyakarat. Modernisasi yang menawarkan nilai-nilai rasionalitas telah merubah konstruksi berpikir masyarakat tentang peran sosial laki-laki dan perempuan. Jaman dahulu perempaun lebih banyak berperan di ruang domestik, sebagai ibu rumah tangga. Sampai saat ini diketahui bahwa perempuan yang mengurus rumah tangga presentasinya jauh lebih besar dibandingkan laki-laki , 
yaitu 37,86 5 untuk perempuan dan 3,65\% untuk laki-laki. Tingginya angka perempuan yang mengurus rumah tangga dibandingkan dengan laki-laki antara lain karena pemikiran tentang kodrat dimana perempuan diciptakan untuk mengurus rumah dan laki-laki mencari nafkah. Namun konstruksi ini terus mengalami perubahan. Dari waktu ke waktu jumlah perempuan yang bergerak di sektor publik semakin banyak. Beberapa faktor yang mempengaruhi tingginya pergeseran jumlah perempuan yang berperan di ruang publik adalah kebutuhan ekonomi keluarga yang semakin tinggi dan tidak cukup ketika hanya suami yang bekerja, adanya peluang kerja atau kesempatan kerja untuk perempuan dan semakin tingginya pendidikan dan ketrampilan perempuan (Nofianti, 2016).

Modernisasi menimbulkan pergeseran cara berpikir masyarakat tentang pembagian peran laki-laki dan perempuan, namun pergseran yang belum sepenuhnya meninggalkan konstruksi lama menempatkan perempuan dalam peran ganda. Ketika perempuan melakukan peran publik, masyarakat tetap menempatkan perempuan sebagai penanggungjawab utama peran domestik. Atau sebaliknya perempuan tidak bisa meninggalkan peran domestik tetapi dituntut untuk masuk ke peran publik. Ada tiga peran perempuan dalam pembangunan yaitu peran reproduktif, produktif dan sosial. Peran reproduktif adalah peran yang berkaitan dengan peran reproduksi yaitu hamil, melahirkan anak, menyusui dan merawat anak-anaknya. Peran produktif adalah peran perempuan melakukan aktifitas yang menghasillkan pendapatan dan peran sosial yaitu peran perempuan dalam membantu masyarakat. Sementara itu peran ganda perempuan terkait dengan tiga fungsi yaitu 1) perempuan sebagai istri, 2) perempuan sebagai ibu, 3) perempuan sebagai anggota masyarakat. Peran sebagai istri adalah peran domestik yang berkaitan dengan pekerjaan-pekerajaan melayani rumah tangga seperti membersihkan dan merawat rumah, memasak mencuci dan pekerjaan rumah tangga yang lain. Peran sebagai ibu adalah peran yang berkaitan dengan persoalan reproduksi seperti mengandung, melahirkan, menyusui, merawat dan mendidik anak. Sedangkan peran sosial adalah peran sebagai anggota masyarakat terkait dengan peran dalam pekerjaan yang mendatangkan pendapatan/gaji (Purtojo, 2007).

Saat ini adal 3 lifestyle prefrerence yang teridentifikasi dan menentukan karakteristik perempuan dalam memilih perannya. Ketiga lifestyle preference tersebut adalah pertama, perempuan yang menempatkan pekerjaan publik atau karir sebagai prioritas (workcentered woman), kedua perempuan yang menggabungkan pekerjaan karir dengan pekerjaan rumah tanpa menempatkan salah satu sebagai prioritas (adaptive woman) dan ketiga, perempuan yang menempatkan prioritas perannya kepada rumah tangga dan kehidupan keluarga (family centered woman) (Browne, 2007). Beberapa ahli membagi peran ganda perempuan ini dalam dua kategori saja yaitu peran domestik dan peran publik. Ada juga yang melihat peran-peran perempuan ini dari beberapa aspek kehidupan yaitu aspek hak, peran sosial, peran politik dan peran ekonomi. Menurut Kurniawan and Mulyani (2018) peran ganda perempuan ini dibagi dalam peran ekonomi dan peran non ekonomi.

Ada beberapa teori yang bisa menjelaskan bekerjanya peran ganda perempuan, yaitu: 1) Perbedaan laki-laki dan perempuan adalah kodrat yang mengindikasikan adanya perbedaan peran masing-masing. Laki-laki dan perempuan memiliki perbedaan kodrat dengan tugasnya masing-masing. Teori ini sering disebut dengan teori nature; 2 ) Peran laki-laki dan perempuan ditentukan oleh terminologi budaya. Jadi laki-laki dan perempuan berperan sesuai dengan harapan-harapan yang telah ditetapkan dalam kebudayannya. Teori ini biasa disebut dengan teori peran; 3) Suami adalah kepala 
keluarga dan istri merupakan kepala rumah tangga, dimana kedua-duanya memiliki posisi yang sama kuatnya; 4) Menempatkan perempuan dalam dunia publik tetapi tidak menempatkan laki-laki dalam dunia domestik; 5)Dalam ranah publik perempuan memiliki hak yang sama dengan laki-laki namun urusan domestik tetep menjadi tanggungajawab perempuan (Nofianti, 2016).

Pergeseran peran perempuan menuju ke ruang publik selain dipengrauhi oleh proses modernisasi dan tingginya kebutuhan ekonomi, juga sangat dipengaruhi oleh keberadaan gerakan feminisme. Gerakan feminisme adalah gerakan yang secara konstruktif berusaha untuk membongkar adanya kepentingan patriarki dalam konstruksi pembagian peran antara laki-laki dan perempuan berbasis gender. Gerakan feminisme berupaya untuk melepaskan masyarakat dari hegemoni patraiarki sehingga tidak bias dalam melihat peran gender antara laki-laki dan perempuan. Ada dua aliran besar pemikiran feminisme yang berpengaruh terhadap bagaimana masyarakat menempatkan peran domestik dan peran publik pada laki-laki dan perempuan. Yaitu aliran feminisme dan aliran soft-feminisme. Aliran feminisme beranggapan bahwa perempuan harus bisa melepaskaan diri dari peran domestiknya, karena peran domestik adalah peran yang dikonstruksikan oleh masyarakat yang dihegemoni oleh budaya patriarki. Dalam aliran ini peran domestik dianggap sebagai perbudakan dari patriarki atau laki-laki. Sementara itu aliran kedua yaitu soft feminisme memiliki cara berpikir dimana peran domestik perempuan itu dianggap sebagai peran yang penting. Menurut Purtojo (2007) peran perempuan sebagai ibu dan istri dalam ranah domestik adalah peran yang penuh makna, peran ibu dan istri adalah potensi perempuan yang memilki kontribusi yang besar dan mulia turut serta dalam membangun masyarakat. Dari keluargalah masyarakat itu terbangun.

Terjadinya pergeseran peran domestik dan peran publik perempuan membuktikan bahwa peran domestik dan peran publik bukanlah persoalan takdir. Sesuai dengan pengertian gender, konstruksi yang menempatkan perempuan hanya dalam ruang domestik saja, atau domestifikasi perempuan merupakan salah satu bentuk "bias" gender. Dikatakan bias karena terjadi kesalahpahaman pada masyarakat dalam memahami perbedaan konsep gender dan konsep jenis kelamin. Konsep peran gender yang diciptakan dan dikonstruksikan oleh masyarakat dipahami sebagai takdir yang tidak bisa dirubah. Sehingga peran pekerjaan domestik yang semestinya bisa dipertukarkan atau bisa dilakukan baik oleh laki-laki maupun perempuan dianggap sebagai takdir bagi perempuan. Perempuan dianggap tidak pantas untuk bekerja di ranah publik dan laki-laki dianggap tidak pantas untuk bekerja di ranah domestik. Pemahaman yang bias seperti ini membatasi perempuan dalam melakukan peran publik dan berdampak pada diskriminasi kepada perempuan serta semakin menjauhkan masyarakat Indonesia dari upaya mewujudkan kasetaraan gender.

\section{Simpulan}

Di dalam RUU Ketahanan Keluarga diatur tentang pembagian tugas antara suami dan istri. Peraturan tentang Ketahanan Keluarga ini dilatarbelakangi oleh beberapa fakta tentang kondisi keluarga di Indonesia, sehingga dipandang perlu untuk mengaturnya dalam sebuah peraturan perundang-undangan. Namun memperhatikan pada bagian dari peraturan perundang-undangan tersebut, yaitu pasal 25 ayat (2) dan (3), memunculkan potensi terjadinya kemunduran menciptakan kesetaraan gender di Indonesia. Pasal tersebut mengatur tentang tugas suami dan tugas istri yang cenderung melakukan proses domestifikasi peran perempuan. Menempatkan perempuan lebih 
banyak di ruang domestik, dan membatasi perempuan berperan di ruang publik dibandingkan dengan laki-laki. Dalam masyarakat yang semakin modern dan struktur keluarga yang berorientasi kepada ekonomi, peran domestik ini sangat membatasi perempuan untuk mendapatkan akses ekonomi. Pembatasan terhadap akses ekonomi secara otomatis akan menempatkan perempuan dalam posisi nomor dua atau lebih rendah dibandingkan laki-laki. Hal ini akan menyebabkan rendahnya penghargaan kepada perempuan, dan berdampak kepada relasi yang tidak seimbang antara laki-laki dan perempuan, dan relasi yang tidak seimbang ini akan menjadi sumber perilaku diskriminasi terhadap perempuan. Rancangan Undang-Undang ini akan membawa upaya kesetaraan gender di Indonesia justru berjalan mundur.

\section{Daftar Pustaka}

Astuti, D. (2020). Melihat Konstruksi Gender Dalam Proses Modernisasi di Yogyakarta. Jurnal Populika, 8(1), 1-13. Retrieved from http://ejournal.widyamataram.ac.id/index.php/populika/index

Aswiyati, I. (2016). Peran wanita dalam menunjang perekonomian rumah tangga keluarga petani tradisional untuk penanggulangan kemiskinan di Desa Kuwil Kecamatan Kalawat. HOLISTIK, Journal Of Social and Culture. Retrieved from https://ejournal.unsrat.ac.id/index.php/holistik/article/view/11188

Browne, J. (2007). The future of gender: Cambridge University Press Cambridge.

Davies, S. G. (2018). Keberagaman Gender di Indonesia: Yayasan Pustaka Obor Indonesia.

Fakih, M. (1996). Analisis gender \& transformasi sosial: Pustaka Pelajar.

Fathoni, R. S. (2020). Domestifikasi Perempuan dalam Gerakan Islam Transnasional di Indonesia 1998-2016 M. Jurnal Wanita dan Keluarga, 1(1), 1-6. doi:https://doi.org/10.22146/jwk.764

Gelgel, N. M. R. A. (2016). Perempuan Gianyar dan Belenggu Ranah Publik dan Privat. Jurnal Kajian Bali (Journal of Bali Studies), 6(1), 173-210-173-210. Retrieved from https://ojs.unud.ac.id/index.php/kajianbali/article/view/19905

Haryatmoko, J. (2016). Critical Discourse Analysis (Analisis Wacana Kritis) Landasan Teori, Metodologi, dan Penerapan. In: Rajawali Press, Jakarta.

Hasan, A., \& Matoka, U. (2016). Analisis Kesetaraan Gender Dalam Penguatan Kelembagaan Universitas Halu Oleo. JURNAL EKONOMI UHO, 1(1). Retrieved from http://ojs.uho.ac.id/index.php/JE/article/view/777

Hasanah, U., \& Musyafak, N. (2017). Gender and Politics: Keterlibatan Perempuan dalam Pembangunan Politik. Sawwa: Jurnal Studi Gender, 12(3), 409-432. 
Retrieved

from https://journal.walisongo.ac.id/index.php/sawwa/article/view/2080

Kurniasari, D. (2021). Partisipasi dan penyerapan tenaga kerja muslimah di sektor informal dalam mendukung pertumbuhan ekonomi yang berkelanjutan. Komitmen: Jurnal Ilmiah Manajemen, 2(1), 75-88. Retrieved from https://journal.uinsgd.ac.id/index.php/komitmen/article/view/12517

Kurniawan, J. S., \& Mulyani, R. W. P. (2018). Peranan Perempuan Dalam Sektor Domestik Dan Publik Di Kelurahan Seminyak, Kecamatan Kuta, Kabupaten Badung, Provinsi Bali. Jurnal Bumi Indonesia, 7(2). Retrieved from http://lib.geo.ugm.ac.id/ojs/index.php/jbi/article/view/1030/0

Mayanti, M. S., \& Bachtiar, N. (2018). Analisis Faktor-Faktor yang Mempengaruhi Partisipasi Penawaran Wanita Menikah untuk Bekerja di Indonesia.

Monica, Y. F., \& Fauziah, L. (2019). Partisipasi perempuan dalam pembangunan desa di Kecamatan Candi. JKMP (Jurnal Kebijakan dan Manajemen Publik), 5(2), 217-228. doi:https://doi.org/10.21070/jkmp.v5i2.1314

Mukodi, M., \& Burhanuddin, A. (2015). Domestifikasi Perempuan Samin Dalam Khasanah Masyarakat Islam Modern. Al-Tahrir: Jurnal Pemikiran Islam, 15(2), 411-430. doi:https://doi.org/10.21154/al-tahrir.v15i2.271

Nofianti, L. (2016). Perempuan di sektor publik. Marwah: Jurnal Perempuan, Agama dan Jender, 15(1), 51-61. Retrieved from http://ejournal.uinsuska.ac.id/index.php/marwah/article/view/2635/0

Nugroho, R. N. (2008). Gender dan strategi pengarus-utamaannya di Indonesia: Pustaka Pelajar.

Perempuan, K. P. (2018). Profil anak indonesia 2018. Jakarta (ID): KPPA.

Purtojo, L. R. (2007). Menyeimbangkan peran publik dan peran domestik (Suatu Konsekuensi atas Peran Ganda yang Dipilih oleh Perempuan). Indigenous: Jurnal Ilmiah Psikologi. doi:https://doi.org/10.23917/indigenous.v0i0.4547

Sukesi, K. (2009). Bias Gender Dalam Pekerjaan Rumah Tangga Domestik Dan Buruh Migran. Jurnal Analisis Sosial, 105-124.

Usman, S. (1998). Pembangunan dan pemberdayaan masyarakat: Pustaka Pelajar. 